\title{
KOMUNIKASI ORGANISASI KEHUMASAN POLRES PASURUAN
}

\author{
M. Alfin Fatikh ${ }^{1}$, Redi Panuju ${ }^{2}$ \\ ${ }^{1,2}$ Universitas dr. Soetomo \\ Email: redi.panuju@unitomo.ac.id
}

Diterima : 3 Januari 2018

Disetujui : 1 Februari 2018

Diterbitkan : 28 Februari 2018

\begin{abstract}
Abstrak
Di era reformasi dan era digitalisasi sekarang ini masyarakat semakin bebas mengupload apa saja di sosial medianya, kasus Begal yang marak di daerah Kabupaten Pasuruan Jawa Timur membuat masyarakatnya resah, ketika ada pelaku Begal tertangkap oleh masyarakat di amuk massa kemudian di rekam lalu di upload dan masyarakat yang menjadi korban menceritakannya di sosial medianya, hingga timbul opini dari masyarakat Pasuruan "City of Begal". Kunci utama keberhasilan humas adalah komunikasi dan opini positif yang di terima oleh masyarakat melalui komunikasinya di media online, opini positif itu akan mengubah opini masyarakat yang beranggapan Pasuruan "City of Begal”. Hasil penelitian ini menunjukkan komunikasi Polres Pasuruan dalam membangun opini positif lebih dominan pada penyampaian informasi kepada Kapolres dan memberikan informasiinformasi keberhasilan tim saber begal untuk membangun isu dan opini positif di masyarakat, Namun komunikasi di media online terhadap masyarakat belum dilakukan, Penerapan konsep pelayanan di media online merupakan bentuk komitmen Polri dalam membangun opini kepada masyarakat. Kualitas komunikasi humas dengan masyarakat di media online perlu ditingkatkan, mengingat masyarakat sekarang lebih banyak membicarakan isu-isu yang terjadi di media online.
\end{abstract}

Kata Kunci : Komunikasi Organisasi, Opini Publik, Media online

\begin{abstract}
In reformation era and digitalization era now people increasingly free to uploade anything in social media. Begal case rampant in Pasuruan of east java to make people restless, when there is a perpetrator of Begal caught by public then recorded and then uploaded and the community who became victims of telling in the social media, so now Pasuruan called is "city of begal". The key to the success of public relations is the sense of security that people received through their online communication, a sense that will change the opinion of people who think Pasuruan "city of begal". The results of this research demonstrate the role definition of Pasuruan Police Public Relationship in providing security more dominant on communications technician and the role of expert prescriber to provide the succes information of the robber cyber team to build issues and opinions positive in society, but the communication facilitator and facilitator troubleshooter persists, though not so dominant. The application of the concept of service in online media is a form of commitment to the Police in providing security to the community. The quality of Public Relation communication with the online media communities needs to be improved, given the many people are talking about issues that occur in the online media.
\end{abstract}

Keywords: Organizational Communication, Public Opinion, Online media 


\section{PENDAHULUAN}

Kepolisian merupakan organisasi yang berada di dalam naungan pemerintah yang mempunyai fungsi sebagai pelindung dan pelayanan masyarakat Indonesia. Ini juga berimbang dengan beriringnya zaman yang kebutuhan masyarakat untuk di ayomi oleh instansi pemerintahan. Polisi merupakan kelompok sosial yang menjadi bagian dari masyarakat itu sendiri, meskipun ada aspek yang berbeda dalam masyarakat umum. Keberadaaan polisi sangat erat kaitanya dengan lapisan masyarakat, karena masyarakat merupakan aktor utama sebagai penerima pelayanan oleh instansi kepolisian.

Salah satunya adalah Polres Pasuruan sebagai alat Negara yang berperan dalam memelihara keamanan dan ketertiban masyarakat dalam rangka menjaga keamanan dalam Negara. Sebagai pengayom masyarakat, Polres Pasuruan harus mampu menjadi penjuru utama untuk mendorong dan membangun informasi serta menjaga opini positif di masyarakat guna mewujudkan masyarakat yang aman dan tertib.

Sejalan dengan perkembangan dunia teknologi dan komunikasi, sebuah organisasi non profit seperti kepolisian memiliki banyak pilihan media yang dapat dimanfaatkan untuk publikasi dan membentuk opini positif di masyarakat. Media merupakan suatu alat yang sangat berperan penting dalam menyampaikan pesan dari pihak komunikator kepada pihak komunikan khlayak. Media saat ini membuat perubahan prilaku masyarakat dalam menyampaikan situasi dan kondisi di masyarakat, kebutuhan informasi yang lebih cepat dan mudah menuntut para pemberi informasi atau komunikasi untuk lebih menguasai bidang teknologi dan komunikasi. Media lahir untuk menjebatani komunikasi antara komunikator dan komunikan yang mempuyai jarak.

Masyarakat saat ini sudah semakin cerdas dan kritis dengan berkembangnya dunia teknologi. Hal ini yang kemudian membuat mereka lebih vokal menyampaikan isu-isu atau permasalahan yang terjadi di lingkungan sekitar. Berbagai isu-isu atau kejadian sering di lontarkan diruang publik melalui berbagai cara baik itu melalui media cetak Koran dalam kolom aduan masyarakat maupun sosial media. Tentu hal ini merupakan realisasi masyarakat sekarang yang cepat menyampaikan pendapat-pendapatnya. Berbagai bentuk ekspresi masyarakat pun sering disampaikan mulai dari menulis di sosial media, turun jalan atau menutup ke jalan, audiensi, hingga mengkritisi berbagai kebijakan. Mengahadapi masyarakat yang kritis terhadap instansi atau organisasi, sebagai lembaga yang dinamis kepolisian juga mampu memberi informasi yang mampu mengubah opini publik yang begitu besar di bicarakan. Dengan kegiatan dan informasi kehumasan mampu merubah opini masyarakat dan membendung pembicaraan masyarakat di sosial media.

Media massa dan sosial media sebagai salah satu pembentuk dan penampung opiniopini masyarakat yang sangat berperan dalam keterbukaan informasi. Media memiliki kamampuan untuk mendisain pembentukan opini-opini yang berkembang di masyarakat, media massa dan sosial media bisa menjadi masukan tercepat oleh sebuah intastansi atau organisasi dan bagaimana organisasi bisa memberikan respon cepat terhadap isu-isu yang berkembang di sosial media agar reputasi dan citra organisasi bisa tetap baik.

Di Kabupaten Pasuruan salah satunya belakangan ini sering terjadi tindak kriminal begal, tindakan yang banyak dilakukan di jalan raya yang sepi. Begal belakangan ini terjadi bukan hanya di kota-kota besar saja melainkan juga terjadi di kota-kota kecil sampai di desadesa, tindak pencurian sepeda motor maupun mobil dengan cara yang sadis (Begal) dan tak segan-segan menghabisi korbanya. Karna para pelaku begal kerap kali melakukan kejahatanya dengan menggunakan senjata tajam untuk menakuti para korban-korbanya. Begal masih menjadi perhatian masyarakat dan media massa, para begal yang terkesan dengan sadisnya dalam menjalankan aksinya masih menjadi banyak pembicaraan masyarakat. Masyarakat Pasuruan merasa terhantui oleh tindak pelaku begal yang begitu 
kejam terhadap korbanya. Terlalu banyaknya tindak begal yang menyelimuti masyarakat Kabupaten Pasuruan membuat isu ini yang bermunculan di berbagai sosial media, mulai dari foto korban begal yang di unggah di sosial media yang beredar membuat semakin maraknya isu begal di Kabupaten Pasuruan. Isu dan kejadian yang berkembang di dalam kehidupan masyarakat membuat masyarakat merasa tidak nyaman dan tidak aman ketika berkendara di daerah Kabupaten Pasuruan.

Semakin banyaknya pelaku begal yang beraksi dan ada yang tertangkap oleh masyarakat sekitar membuat emosi masyarakat di luapkan dengan berbagai cara, salah satunya dengan menghakimi pelaku, dan ada juga yang sampai dibakar hidup-hidup. Ketika masyarakat melaporkan kepada polisi maka akan di amankan oleh polisi agar tidak menjadi korban kemarahan masyarakat. Dalam proses menghakimi para pelaku begal, masyarakat sering kali mengabadikannya dan di unggah di sosial media. Dari dokumentasi itu membuat orang-orang diluar daerah Kabupaten Pasuruan juga mempunyai rasa takut untuk melintasi daerah Kabuapten Pasuruan. Karna pengguna sosial media tidak terpaku dengan satu daerah saja. Dari isu dan kejadian yang berkembang di sosial media ini membuat semakin cepatnya informasi begal di terima oleh semua masyarakat membuat rasa aman di masyarakat berkurang.

Namun untuk mengimbangi maraknya begal di lapangan dan informasi begal yang di upload oleh tidak cukup dengan penyebaran tim saber begal yang bertugas. Akan tetapi perlu adanya penguatan informasi di media dalam mengkonter isu dan kejadian yang telah meresahkan masyarakat ini. Dalam hal ini humas sangat penting dalam menjalankan tugasnya selain sebagai fasilitator komunikasi, humas juga pembentuk opini positif masyarakat juga sebagai media penyalur informasi lembaga kepada masyarakat. Hubungan masyarakat tidak bisa lepas dari perannanya dalam mengkonter isu-isu yang terjadi di dalam organisasinya, humas harus memiliki kemampuan untuk mengkonter isu atau opini di masyarakat menjadi opini yang positif. Humas juga harus memiliki rencana yang berkesinambungan dalam rangka menciptakan dan memelihara niat baik dan saling pengertian antara polres sebagai pengayom kepada masyarakat.

Karena humas punya kewajiban untuk memberikan informasi dan menerima informasi dari publiknya, serta menampung keinginan-keinginan dan aspirasi masyarakat. Sehingga sebagai praktisi kehumasan memahami aspek yang sangat penting dalam komunikasi dan informasi tentang kebutuhan dan harapan publik, agar informasi dan komunikasi bisa memberi opini positif dan munculnya reputasi baik di mata masyarakat. Masyarakat banyak di suguhi informasi tentang tindak kejahatan jalanan (Begal) di sosial media. Pemberitaan yang cukup tinggi di kabupaten pasuruan berakibat kecemasan bagi masyarakat, namun dengan sosial media ini memiliki sisi baik bagi masyarakat dalam hal kewaspadaan sejak dini karena dalam penyebaranya sangat cepat meski begitu banyak kecamasan dalam masyarakat. Di era digitalisasi masyarakat banyak menggunakan sosial media untuk meluapkan apa yang sekarang di rasakan, banyak sosial media yang di pakai oleh masyarakat, mulai dari Facebook, Instagram, Twitter dan Path. Sosial media ini yg biasanya di pakai oleh masyarakat untuk meluapkan kasus begal yang ada di lingkunganya.

Disinilah keberadaan humas sangat betul-betul penting dalam menopang kerja kepolisian saat berkomunikasi dengan masyarakat. Keahlian menjalankan fungsi praktisi kehumasan secara profesional dan baik merupakan sebuah instrumen untuk membangun komunikasi agar masyarakat bisa menerima apa isi komunikasi dari instansi dan organisasi, sehingga mewujudkan opini positif di mata masyarakat. Ketika kerja kepolisian di lapangan tanpa di imbangi oleh penyebaran informasi yang baik maka akan sulit di ketahui oleh masyarakat luas. Disinlah media komunikasi kehumasan Polres Pasuruan menjadi jembatan untuk mendekatkan isu dan opini kepada semua lapisan masyarakat. Bagaimana komunikasi 
humas Polres Pasuruan dalam membangun opini positif di media online dan timbal balik serta media apa yang di gunakan?

\section{METODE PENELITIAN}

Teori Gruning tentang model Two Way symmetrical adalah model komunikasi simetris dengan dua arah atau timbal balik yang menggambarkan bahwa sebuah propaganda atau kampanye melalaui komunikasi dua arah atau timbal balik yang berimbang. Model ini bisa untuk memecahkan sebuah konflik dan memperbaiki pemahaman publik dengan menggunakan media komunikasinya. Pesan yang disampaikan dapat diterima dan dianggap lebih etis dalam menyampaikan pesan atau sebuah informasi melalui teknik komunikasi yang di pakai oleh organisasi untuk membujuk dan membangun suatu hubungan dengan masyarakat untuk saling pengertian, mendukung dan saling memahami kondisi permasalahan yang ada.

Model ini akan di kaitkan dengan permasalahan yang menjadi inti penelitian, maka terjadi komunikasi dua arah dan timbal balik antara pihak humas Polres Pasuruan dan masyarakat. Memberikan informasi atau berita tentang keberhasilan menangani kejahatan jalanan (Begal) untuk meredam dan membangun opini positif kepada masyakat karna kasus begal yang sampai sekarang masih marak.

Menurut Pace dan Faules ada dua perspektif utama yang akan mempengaruhi bagaimana komunikasi organisasi, yaitu: (1) persepktif objektif dan (2) perspektif subjektif. (Face dan Faulus 2015 : 33) Perspektif objektif menenakan pada definisi sebuah komunikasi sebagai petunjuk dan arah penafsiran pesan komunikasi organisasi yang merupakan bagian dari suatu organisasi tertentu. Perspektif objektif lebih mengarah pada penanganan pesanpesan, mulai dari menerima, menafsirkan dan bertindak berdasarakan informasi dalam suatu peristiwa komunikasi organisasi. Komunikasi di pandang sebagai alat untuk merekayasa organisasi untuk mengadaptasikan para pelaku organisasi kepada lingkungan internal dan ekasternalnya. Perspektif subjektif mendefinisikan komunikasi organisasi sebagai proses menciptakan makna atas interaksi diantara unit-unit komunikasi untuk menciptakan, memilhara dan mengubah organisasi. Subjektif ini lebih mengarah pada bagaimana individu anggota di dalam organisasi berinterakasi dan memberikan makna terhadap peristiwaperistiwa komunikasi yang terjadi. Dengan makna lain pelaku komunikasi organisasi berprilaku akan bergantung pada pemaknaan informasi.

Secara struktural PR merupakan bagian integral dari suatu organisasi dimana PR merupakan salah satu fungsi manajemen modern yang bersifat melekat pada manajemen perusahaan (corporate management function). Hal tersebut berarti PR dapat berperan dalam melakukan komunikasi timbal balik (two ways communications) dengan tujuan menciptakan serta memelihara sikap saling pengertian (mutual understanding), saling mempercayai, saling mempercayai, menciptakan goodwill, memperoleh dukungan publik dan demi terciptanya corporate image yang positif (Soemirat \& Ardianto, 2010).

Komunikasi kehumasan menjadi pendukung sebuah program dan aksi yang dilakukan oleh humas dalam mendasari penanganan sebuah masalah, ada 4 yang di tawarkan oleh Cutlip, Center dan Broom. (1) Defining Public Relations Poblems, langkah ini untuk menyelidiki opini penyelidikan opini, sikap dan dipengaruhi oleh tindakan dan kebijakan organisasi. (2) Planning and programming, Informasi yang telah di kumpulkan pada langkah pertama di gunakan untuk membuat dasar program, strategi komunikasi dan taktik. (3) Taking action and communicating, Implementasi Program aksi dan komunikasi yang didesain untuk mencapai publik yang sesuai dengan tujuan. (4) Evaluating and program, Langkah terakhir ini mengevaluasi terhadap langkah-langkah, mulai dari perencanaan, implementasi dan program. Tahap ini melihat keberhasilan dari program yang kita lakukan. 
Fungsi komunikasi organisasi ini sangat berpengaruh terhadap komunikasi PolresPasuruan dalam membangun opini positif di masyarakat, fungsi komunikasi ini perlu dibedakan antara organisasi profit dan organisasi non profit. Agar komunikasi ini bisa lebih efektif di sampaikan (Kodir dan Susilo, 2015):

(1) fungsi secara regulatif berkaitan dengan fungsi-fungsi yang berlaku yang didasari oleh aturan-aturan di dalam organisasi, Atasan atau orang-orang yang berada di dalam tataran manajemen yaitu mereka yang memiliki keputusan dan wewenang untuk mengendalikan semua informasi di sampaikan. Juga memiliki wewenang instruksi dan perintah. pesan, pesan-pesan regulatif pada dasarnya berorientasi pada kerja, artinya pesan kepastian peraturan kepada bawahan tentang pekerjaan yang boleh dan tidak boleh untuk di laksanakan.

(2) fungsi secara persuasif Fungsi menekankan pada komunikasi kekuasaan dan wewenang membawa hasil yang sesuai dengan apa yang kita harapkan. Banyak pimpinan yang lebih suka mempersuasif bawahnay dari pada memerintah. Karan pekerjaan yang dilakukan dengan suka rela dan rasa seang akan membuat dan menghaslikan kepudulian yang lebih besar.

(3) fungsi secara informatif Orgnisasi sebagai sebauh sistem yang memproses informasi (information processing system) yang memiliki tujuan seleuruh anggota yang terlibat dalam organisasi berharap dapat memperoleh yang lebih banyak, leboh baik dan tepat waktu. Informasi yang didapat memeungkinkan setiap anggota organisasi dapat melaksanakan pekerjaan secara lebih pasti.

(4) fungsi secara integratif Setiap organisasi berusah menyediakan saluran yang memungkinkan dapat melaksanakan tugas dengan baik. Ada dua bentuk saluran komunikasi formal, penerbitan khusus seperti (newsletter, bulletin) dan laporan kemajuan organisasi. Kalau saluran komunikasi informal seperti perbincangan saat para pelaku organisasi berinstrirahat.

Komunikasi Pemerintahan adalah sebuah penyampaian ide, progam kerja, dan gagasan Pemerintah kepada publik dalam rangka mencapai tujuan negara. Dalam hal ini Pemerintah dapat di jadikan sebagai komunikator dan masyarakat sebagai komunikan, namun dalam hal tertentu bisa sebaliknya publik berada pada posisi sebagai penyampai ide-ide baru atau gagasan dan Pemerintah berada pada posisi menerima pesan apa yang diinginkan masyarakat. Hubungan masyarakat sebagai fungsi manajamen, setiap organisasi harus memperhatikan adanya sebuah humas di dalam organisasinya. Sifat terpenting komunikasi organisasi adalah penciptaan pesan, penafsiran, dan penanganan kegiatan organisasi. Bagaimana komunikasi berlangsung dalam organisasi dan apa maknanya bergantung pada konsepsi seseorang mengenai organisasi. (Pace \& Faules : 2015)

\begin{tabular}{|l|l|}
\hline \multicolumn{1}{|c|}{ Kajian } & \multicolumn{1}{c|}{ Sub Kajian } \\
\hline Komunikasi Organisasi & - Pengiriman \& penerimaan pesan \\
& - Komunikasi formal \& informal \\
& - Media komunikasi \\
& - Monitor isu dan opini masyarakat \\
\hline Kehumasan & - Mengendalikan isu yang terjadi \\
& - Kegiatan dan keberhasilan saber begal di update di media \\
& komunikasi dan media cetak \\
& - Menginformasikan tempat-tempat rawan begal \\
\hline Media komunikasi & - Website resmi Polres Pasuruan \\
& - Sosial media polres, twitter, facebook dan instagram \\
& - Koran online berita daerah Kab. Pasuruan \\
\hline
\end{tabular}




\begin{tabular}{|c|c|}
\hline Dimensi & Indikator \\
\hline Komunikasi Organisasi & $\begin{array}{l}\text { 1. Optimalisasi tujuan } \\
-\quad \text { Komunikasi humas mampu membangun opini di } \\
\text { masyarakat } \\
-\quad \text { Menjaga hubungan baik dengan stakeholder } \\
\text { - Media komunikasi Polres Pasuruan } \\
\text { 2. Media komunikasi } \\
\text { - Website resmi Polres Pasuruan. } \\
-\quad \text { Sosial media : Facebook, twitter dan instagram. }\end{array}$ \\
\hline Media & $\begin{array}{l}\text { 1. Ketepatan memilih media } \\
\text { 2. Adanya upaya persuasif untuk membangun opini di } \\
\text { lingkungan sekitar } \\
\text { 3. Pola komunikasi mengatasi begal yang kerap terjadi } \\
\text { 4. Media online sebagai peran tercepat dalam membangun opini } \\
\text { 5. Adanya respon dari masyarakat terhadap berita begal. }\end{array}$ \\
\hline
\end{tabular}

Gejala tersebut jangan di campuradukkan dengan gejala yang lain yang tidak mempuyai hubungan, atau sebuah intervensi-intervensi yang berasal dari sisi kebudayaan, kepercayaan atau dari ilmu pegetahuan yang telah kita miliki. (Meleong : 2001). Metode riset dimana periset melakukan kegiatan observasi dan wawancara tatap muka secara mendalam dan terus menerus untuk menggali informasi dari responden (Kriyantono, 2008). Melalui observasi atau pengamatan berperan serta, peneliti dapat berpartisipasi dalam rutinitas subjek peneliti baik mengamati apa yang mereka lakukan, mendengarkan apa yang mereka katakan, dan menanyai orang-orang disekitar mereka selama jangka waktu tertentu. (Mulyana, 2004). Dari cara ini akan menghasilkan data yang berupa tertulis atau lisan dari orang-orang yang diamati, dengan berusaha menggambarkan obyek-obyek yang kita teliti berdasarkan fakta di media dan di lapangan.

Aktivitas dalam analisis data kualitatif dilakukan secara interaktif dan berlangsung secara terus menerus sampai tuntas hingga datanya mencapai titik jenuh. Teknik analisis data menggunakan analisis data kualitatif model interaktif dari Miles dan Huberman (Sugiyono, 2013). Berdasarkan tujuan penelitian untuk mencatat, menganalisa dan menginterpretasikan kondisi yang telah terjadi, dengan di imbangi oleh informasi mengenai manusia sebagai obyek dari penelitian. Yaitu reduksi data, penyajian data, penarikan kesimpulan atau memverifikasi secara interaktif saling berhubungan antara praktisi humas Polres Pasuruan dengan bukti di sosial media.

Sumber data merupakan bukti data dalam sebuah penyajian informasi yang didukung oleh wawancara dengan para pelaku kehumasan Polres Pasuruan dalam memberikan informasi kepada masyarakat. Sumber data di dalam penelitian kualitatif adalah kata-kata dan tindakan, selebihnya adalah tambahan data seperti dokumen dan sebagainya. Ini di sebabkan karna penelitian kualitatif cenderung mengutamakan wawancara dan pengamatan langsung (observasi) dalam memperoleh data yang bersifat tambahan. ( Loflend and Moleong : 2006 )

Penelitian ini menggunakan pendekatan fenomenoligi untuk mengupas dan menjawab dari pertanyaan peneltian yang terdapat pada titik fokus penelitian. Fenomenogi merupakan usaha untuk memahami sebuah arti dan fenomena yang terdapat pada permasalahan, dalam pendekatan ini tidak bisa dipungkiri bahwa asumsi-asumsi dasar dari pelaku humas polre pasuruan menyelimutinya. Dengan pendekatan fenomenologi peneliti berusaha menggali nilai yang terdapat padapegalaan dalam setiap hari dalam memberikan informasi dan komentar masyarakat di social media humas Polres Pasuruan. 
Sedangkan untuk menguji keabsahan data yang telah terkempul dari hasil peneletian sehingga data yang di dapat bisa benar-benar sesuai dengan tujuan dan maksud penelitian, maka menggunakan teknik triangulasi. Menggabungkan dari berbagai teknik pengumpulan data dan sumber data yang telah ada. maka sebenarnya peneliti mengumpulkan data sekaligus menguji kreadibilitas data yang sudah ada, yaitu dengan mengecek kreadibilitas data dari berbagai teknik pengumpulan data dan berbagai teknik pengumpulan data dan berbagai sumber data.

\section{DISKUSI DAN ANALISIS}

\section{Komunikasi Organisasi}

Berdasarkan tugas pokok fungsi hubungan masyarakat Polisi Republik Indonesia (Polri) Humas wajib melaksankan konfrensi pers, menyusun hak jawab koreksi, menganalisa berita, dan membangun opini pembentukan opini melalui publikasi kegiatan Polri.

Dalam menghadapi dinamika komunikasi masyarakat di media online yang begitu deras membicarakan kasus begal yang marak di Kabupaten Pasuruan tidak bisa dihentikan. Maka komunikasi dan informasi yang bisa membuka untuk memperbaiki opini yang sudah banyak di bicarakan masyarakat. Arah sebuah institusi atau organisasi di masa depan akan sangat berpengaruh pada dinamika isu dan opini yang berkembang di masyarakat, kemampaun komunikasi dan mengidentifikasi secara dini di masyarakat merupakan tahapan awal yang penting dalam menentukan arah prioritas untuk menangani komunikasi kedepanya.

Dalam aliran komunikasi humas Polres Pasuruan di bagi menjadi dua yaitu komunikasi di media online dan komunikasi yang mempunyai dampak di dalam organisasi, aliran komunikasi yang dilakukan oleh humas Polres Pasuruan yaitu dengan komunikasi informatif yang menyampaikan suatu berita atau informasi kepada publiknya sesuai dengan kondisi atau keadaan yang telah dilakukan diluar ataupun di dalam organisasi. Dalam menghadapi opini negatif yang begitu deras di sosial media humas Polres Pasuruan tidak memilah mana publik yang aktif -pro, aktif - kontra, pasif dan media apa yang di pakai. Kategori publik atau masyarakat ini yang membicarakan kasus begal di sosial media perlu di bedakan dalam berkomunikasi, agar lebih efektif informasi yang kita sampaikan bila sesuai dengan kategori masyarakat yang ada. Namun, humas Polres Pasuruan tidak memberi katogori dalam menyampaikan informasi, humas langsung menginformasikan secara menyeluruh.

Cara komunikasi humas Polres Pasuruan tidak membangun opini positif di media online, akan tetapi penguatan melalui informasi yang khususnya informasi tentang keberhasilan tim saber begal, humas tanpa memilah dan melihat sasaran pembaca. Sehingga metode yang dilakukan dalam menyampaikan secara merata kepada publiknya di media online. Selain komunikasi organisasi informatif secara merata, humas Polres Pasuruan juga tidak melakukan komunikasi yang baik dengan masyarakat, hanya membangun komunikasi baik dengan pihak wartawan, dan pers media online. Sedangkan untuk mempengaruhi masyarakat, humas mengandalkan informasi tim saber begal dengan menerapkan prinsip :

1. Penguatan Informasi

Hal ini adalah keterbukaan peran polisi di lapangan di untuk menguatkan informasi kepada masyarakat bahwa polisi itu ada dan bertindak ketika masyarakat di hantui dengan kejadian begal yang arak di bicarakan di media online. Humas Polres Pasuruan melakukan asas keterbukaan informasi kepada semua lapisan stakeholder dengan dasar milik pemerintah, hal ini diimplementasikan kepada semua lapisan internal dan eksternal untuk menguatkan informasi-informasi keberhasilan tim saber begal untuk mengubah isu dan opini negatif yan banyak dibicarakan oleh masyarakat. 
Penguatan informasi ini dilakukan oleh humas polres untuk membnagun opini positif di masyarakat melalui media online, berita tentang perkembangan kasus begal menjadi prioritas untuk di sebar kepada masyarakat melalui media komunikasinya.

Aliran komunikasi humas Polres Pasuruan pada langkah awal sebatas melihat dan menjadi monitoring opini publik atau isu-isu yang berkembang di masyarakat yang bersangkutan dengan kegelisahan masyarakat, rasa aman, dan kejadian-kejadian tentang hukum, hubungan masyarakat melihat opini publik dan isi-isu yang berkembang melalui media online dan perkembanganya isu yang terjadi setelah itu di laporkan kepada atasan. Karna pembicaraan masyarakat saat ini bukan hanya dilakukan di dunia nyata akan tetapi juga banyak opini dan isu-isu yang berkembang di masyarakat lebih banyak diluapkan di media online atau sosial media untuk lebih banyak orang yang membaca dan mengomentarinya. Dari isu dan opini masyarakat yang negatif dimonitor oleh humas Polres Pasuruan kemudian kepala humas mencatat dan berkomunikasi kepada kepala dan Wakapolres untuk menjadi bahan masukan apa yang sedang di bicarakan masyarakat tentang organisasinya.

Untuk penanganan media online yang menjadi tempat opini publik dan isu yang berkembang di telinga masyarakat, para praktisi hubungan masyarakat Polres Pasuruan mengimbangi dengan kerja keras kapolres dan tim saber begal yang disebar di tempat-tempat rawan dan selalu di informasikan di oleh hubungan masyarakat polres. Karna awal penanganan humas hanya mengandalkan monitor dan respon masyarakat yang berkembang.

2. Hubungan baik dengan wartawan

Humas Polres Pasuruan terus berusaha menanamkan dan mengembangkan hubungan baik kepada semua wartawan dan pers untuk penguatan informasi-informasi kepada masyarakat melalui media pers yang dimiliki. Humas polres pasuruan membangun ini dengan tujuan agar keberhasilan tim saber begal bisa diliput terus dan di beritan oleh semual wartawan, agar opini di masyarakat yang membicarakan pasuruan sebagai kotanya begal bisa hilang. hubungan baik ini juga terlihat dan dilakukan oleh humas polres pasuruan kepada media Warta Bromo (Koran Online) Pasuruan, kepala humas mengajak Wakapolres untuk memberikan kue ulang tahun kepada ketua Warta Bromo waktu ulang tahun. Ini dilakukan karena media Warta Bromo yang begitu aktif memberitakan perkembangan berita begal dan keberhasilan tim saber begal dalam menangkap pelaku-pelaku dan daftar pencarian orang (DPO) begal.

Dalam hal isi banyaknya pembegalan di Kabupaten Pasuruan, hubungan masyarakat Polres Pasuruan sangat berkompenten dan menjadi pintu masuk komunikasi masyarakat yang aktual dan akurat tentang perkembangan media online dalam lembaga kepolisian dalam menangani berbagai permasalahan keamanan di wilayah hukumnya. Karna masalah yang muncul bukan hanya di lapangan akan tetapi di dunia media online.

Tidak ada komunikasi dalam memecahkan masalah yang di berikan oleh humas Polres Pasuruan di kepada masyakat langsung media online. Ketika ada masyarkat yang meluapkan ketakutan dan gambar-gambar korban begal di upload di masyarakat yang di sampaikan di sosial media, humas tidak ikut berkomentar untuk memberi dan masuk untuk mengubah isu dan opini publik yang berbicara tentang keamanan wilayah hukum Pasuruan.

Dalam komunikasi kasus begal yang ramai di bicarakan di media online, humas Polres Pasuruan tidak melakukannya dalam membangun opini positif secara langsung kepada masyarakat, namun mengimbangi isu, opini publik yang banyak dibicarakan oleh masyarakat Kabupaten Pasuruan maupun luar Pasuruan di media online dengan penguatan informasi. Humas belum melakukan komunikasi pemecahan masalah yang dialami oleh 
masyarakat, humas hanya mengandalkan kegiatan tim saber begal dan kerja satreskrim untuk di informasikan kepada masyarakat.

Sebagai komunikator hubungan masyarakat harus bertindak sebagai mediator dalam kasus begal untuk menjadi jembatan antara keinginan publik dan keinginan instansinya. Polisi sebagai lembaga pemerintah yang memberi keamanan dan ketertiban di masyarakat menjadi perbincangan masyarakat ketika masyarakat di selimuti oleh kasus pembegalan yang hampir setiap hari terjadi, akan tetapi pihak hubungan masyarakat tidak membuka komunikasi agar masyarakat bisa berkomunikasi langsung dengan pihak kepolisian. Hubungan masyarakat Polres Pasuruan berpendapat ketika isu dan opini yang terus berkembang instansi hanya melihat dan memonitor kejadian yang ada, bukan menjadi pembangun dan pencegah opini yang berkembang untuk membuka ruang kecemasan dan ketakutan masyarakat.

Ketika di facebook berita online Warta Bromo yang sangat di gemari masyarakat Pasuruan, mengupload video pelaku begal yang di massa oleh masyarakat di daerah Nguling,

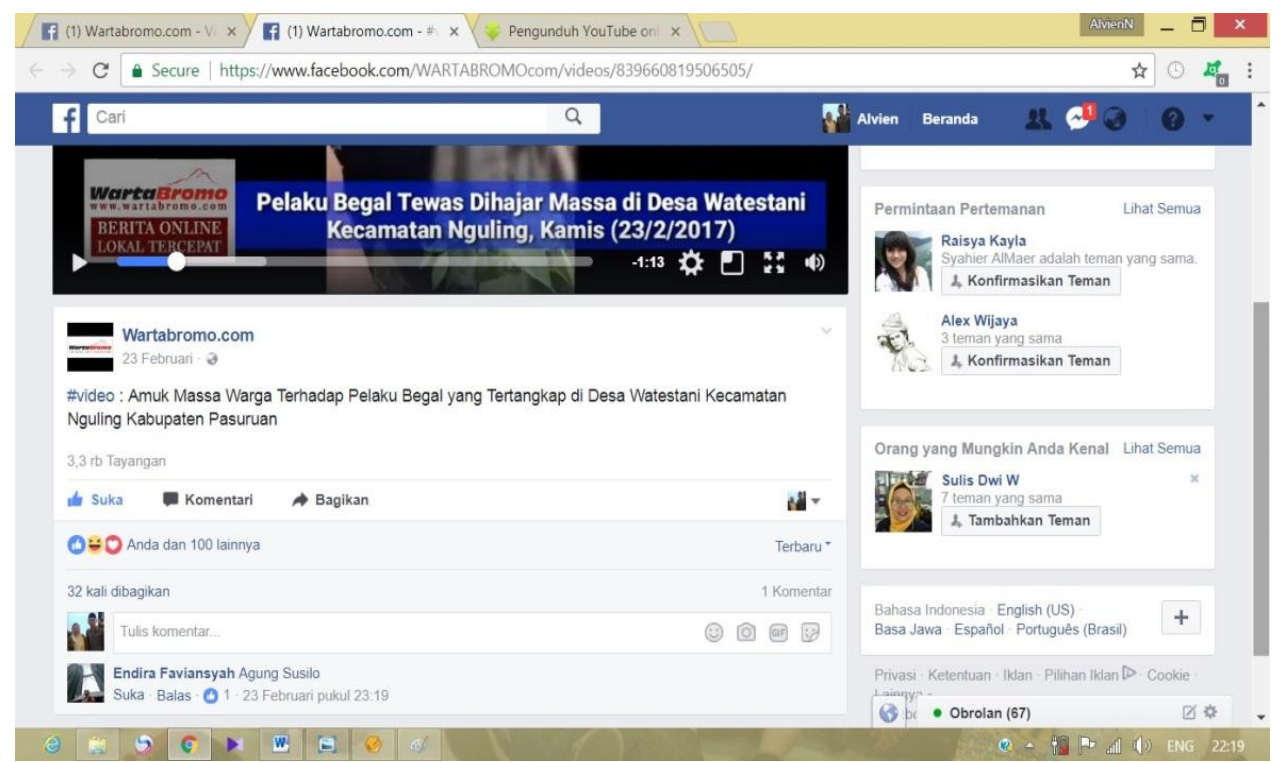

hubungan masyarakat Polres Pasuruan tidak terlihat berkomentar dan tidak membangun komunikasi kepada masyarakat. Padahal masyarakat yang menonton video tersebut sangat banyak, mencapai 3,3 Ribu orang yang menonton.

Ketika melihat penonton video begal di media Warta Bromo yang begitu besar sudah mencapai 3 ribu, ini merupakan kesempatan hubungan masyarakat Polres Pasuruan untuk masuk di dalamnya untuk menjadi jalan atau menjadi jembatan komunikasi untuk mendekatkan dengan masyarakat. Akan tetapi disini humas Polres tidak terlihat berkomentar dengan kondisi masyarakat yang terselimuti kasus begal. Humas hanya mengandalkan informasi-informasi yang di publikasikan oleh melalui media komunikasnay sendiri.

Komunikasi yang di berikan oleh humas Polres Pasuruan hanya sekedar merespon ketika masyarakat chat melalui medianya. Padahal dengan humas Polres Pasuruan memfasilitasi komunikasi dengan intansinya akan ada aspirasi yang masuk. Aspirasi masyarakat dan keinginanya butuh di dengar oleh pihak kepolisian dalam adanya sebuah kasus. Dari partisipasi dan keluhan masyarakat inilah kepolisian bisa membuat program sesuai dengan keluhan masyarakat.

Hal ini bisa terlihat dengan maraknya kasus kejahatan pencurian dan kekerasan (Begal) yang di alami oleh masyarakat Kabupaten Pasuruan, masyarakat dan tokoh masyarakat tidak mempunyai wadah untuk mengaduh kasus maraknya begal. Ketika komunikasi tidak dibangun oleh humas di media online kepada masyarakat yang meluapkan 
ketakutanya ini menjadikan masyarakat langsung ke Polres tidak mengerti ke bagian apa untuk meluapkan kegelisahanya, sampai banyak masyarakat yang mempunyai cara sendiri untuk menemui Kapolres langsung ketika di daerahnya mengalami banyaknya kasus begal dan sudah diluapkan di media online akan tetapi tidak ada respon. Masyarakat mengikuti sholat jum'at di markas Polres Pasuruan bersama kepolisian, kemudian setelah sholat jum'at selesai masyarakat ini menunguh bapak kapolres kelaura dari masjid, masyarakat mendekati kepada bapak Kapolres untuk menceritakan kasus-kasus yang di alami di daerahnya dan menceritakan kalau sudah banyak informasi secara mulut ke mulut dan di media online. Dari kejadian ini humas Polres Pasuruan belum bisa membangun opini positif kepada masyarakat di media online. Karna media sebagai jembatan komunikasi publik tidak tersambung dengan masyarakat yang mengalami keresahan hingga masyarakat berkomunikasi langsung dengan Kapolres AKBP. Muhammad Aldian, SIK., MH.

Selain humas sebagai pelaku komunikasi Polres Pasuruan juga sebagai komunikator media dalam peranan nya, humas dalam hal ini sangat berperan aktif dalam menjadi komunikator media, karena sekarang komunikasi yang banyak di gemari oleh masyarakat adalah komunikasi di media online.

Sebagai komunikator media khususnya yang berkaitan dengan press release, brosur, website, sosial media. Di sisi lain humas Polres juga harus lebih aktif memberikan dan menyediakan informasi kepada kepada publik eksternal ataupun internal dalam bentuk apapun. Dalam penyebaran informasi dari humas polres Pasuruan kepada masyarakat Polres mempuyai lima media yang biasanya di gunakan untuk memberikan informasinya.

Media yang digunakan oleh humas Polres Pasuruan ialah Website, facebook, instagram, twitter dan path. Dari lima media ini humas Polres tidak menggunakanya semua untuk membangun opini positif kepada masyarakat, hanya website dan instagram yang aktif memberikan informasi perkembangan dan membangun opini positif dalam kasus banyak begal.

Dalam memberikan informasi dan komunikasi kepada masyarakat, humas Polres Pasuruan selain mengandalkan website dan instagramnya juga mengandalkan press realease sebagai penguatan informasi untuk membangun opini positif kepada masyarakat. Karna informasi atau berita lokal lebih banyak bermain di media online, dengan media-media atau Koran online inilah humas polres memanfaatkan untuk bisa membangun opini publik kepada masyarakat. humas sendiri mengakui kalau humas nya masih belum bisa menjangkau kepada masyarakat khususnya di kasus begal di jalanan sampai di menjadi pembicaraan banyak orang di sosial media.

Memang bisa terbukti dengan temuan data di lapangan humas Polres Pasuruan tidak ikut masuk dalam komentar-komentar masyarakat untuk meredam isu dan opini negatif yang berkembang pesat di sosial media. Humas Polres Pasuruan lebih pada mengimbangi dan memberikan informasi sebagai penguat kepada masyarakat tidak pada membangun opini positif.

\section{Media Online}

Media konfensional saat ini memang sudah banyak mulai di tinggalkan oleh masyarakat Indonesia, dengan canggihnya era teknologi dan percepatan informasi dan komunikasi yang dimiliki oleh media online ini saat dicintai oleh masyarakat. Khususnya sosial media yang begitu disukai oleh masyarakat Indonesia, maka jika tidak heran masyarakat Indonesia dalam memberikan informasi dan komunikasi yang biasanya banyak di bicarakan bersama-sama sambil berkumpul barsama keluarga, teman, tetangga dan orang lain sekarang mulai bergeser pada untuk membicarakanya di media online. 
Kepolisian dalam penguatan informasi juga tidak hanya ada di dunai nyata akan tetapi juga bergeser pada media online. Informasi dan komunikasi yang di luapkan oleh masyarakat dalam maraknya kasus pencurian dan kekerasan (begal) di Kabupaten Pasuruan ini menjadi pekerjaan Hubungan masyarakat Polres Pasuruan.

Humas Polres Pasuruan dalam membangun opini positif kepada masyarakat mempunyai lima media untuk menjaungkau infomasi dan komunikasi kepada masyarakat. Namun dari lima media online yang digunakan oleh humas polres hanya 2 yang aktif menyampaikan informasi dan mengimbangi opini masyarakat yang negatif, humas dalam penguatan informasi keberhasilan tim saber begl dan tim satreskrim Pasuruan Polres kepada masyarakat melalui dengan website, instagram. Dalam memberikan informasi untuk mengimbangi opini positif kepada masyarakat di twitter hanya dengan berbentuk teks tanpa ada gambar dan video, di dalam twitter humas Polres Pasuruan dalam penguatan informasi dan opini positif juga di beri link pada Instagramnya.

Website Polres Pasuruan yang di kendalikan oleh hubungan masyarakat dalam penguatan informasi untuk mengimbangi opini negatif mengenai kasus maraknya begal isinya tidak imbang dengan di sosial media Instagram. Website resmi Polres Pasuruan digunakan oleh hubungan masyarakat untuk memberikan informasi kejadian yang begitu besar, seperti tertangkapya pimpinan begal saudara Tuhar dan pembentukan tim saber begal. Akan tetapi untuk informasi daftar pencarian orang (DPO) begal dan perkembangan kasuskasus begal humas polres tidak memasukkan kedalam website resminya.

Website hanya sekedar menyebar informasi yang yang di anggap besar ole humas akan tetapi informasi yang tidak begitu besar akan masuk pada instagram humas Polres Pasuruan, humas dalam penguatan informasi melalui berita-beritnya dan kegiatanya tidak lengkap seperti informasi yang di sampaikan di sosial media Instagram Polres Pasuruan. humas Polres Pasuruan ingin mendekatkan diri dan membangun opini positif kepada masyarakat dalam kasus begal menggunakan media online yang banyak di gemari oleh masyarakat, agar informasi dan komunikasi yang di berikan oleh humas Polres Pasuruan cepat di terima oleh public, polres menggunakan Instagram sebagai sarana medianya. Kalau humas lebih mengandalkan websitenya tanpa masuk kedalam sosial media masyarakat maka akan lebih sulit untuk menjangkau isu dan opini yang di perbincangkan banyak masyrakat.

Humas Polres Pasuruan lebih banyak menggunakan instagram dalam menyebar informasi di dalamnya, humas mengikuti trend masyarakat ber sosial media agar kegiatan dan kerja Polres bisa tersampaikan kepada masyarakat. Namun di instagram humas Polres Pasuruan hanya lebih banyak memberikan informasi keberhasilan penangkapan DPO begal dan kerja keras tim saber begal dari pada membangun opini positif kepada masyarakat.

Terlihat dengan gambar, teks dan respon masyarakat dalam kasus kejahatan jalanan begal ini, dalam informasi yang di berikan di instagram oleh humas Polres dari hasil kerja keras tim saber begal dan satuan reserse kriminal Polres Pasuruan. Padahal dari instagram sendiri masyarakat yang memberi like dan berkomentar tidak terlalu banyak, dibandingkan dengan berita kasus begal yang di upload oleh Koran online Warta Bromo yang sudah mencapai 3 ribu lebih. Ini artinya humas Polres Pasuruan masih belum bisa memilih jembatan komunikasi dalam membangun opini positif kepada masyarakat.

Di dalam instagram judul berita masih kental dengan bahasa hukum, judul yang dipakai lebih mengarah kepada bagaimana isu dan opini publik yang negatif tentang banyaknya masyarakat yang membicarakan di media online ini bisa terimbangi oleh informasi dan kinerja Polres, akan tetapi menempatkan media sebagai jembatan komunikasi kepada masyarakat masih belum tepat. Karna masyarakat akan melihat website Polres Pasuruan bila ada keperluan saja. 
Berbedah ketika Humas Polres Pasuruan memberikan informasi melalui instagram dan facebook yang banyak di gunakan oleh masyarakat Indonesia. Karna dengan sendirinya masyarakat akan melihat informasi yang masuk pada beranda facebook dan instagram. Instagram menjadi media utama dalam menyebarkan informasi untuk mengubah isu dan opini publik. Ketika humas Polres Pasuruan mengandeng Koran online lokal untuk menyebar beritanya akan lebih baik, karna jumlah pengikutya jauh lebih besar dan banyak dari pada pengikut instagram dan pengunjung website Polres Pasuruan.

Di instagram humas Polres Pasuruan memamerkan media-media online yang di gunakan, akan tetapi media tersebut tidak aktif bahkan masih belum di buat akan tetapi di pamerkan terlebih dahulu. humas ketika bisa memanfaatkan facebook dan Koran online sebagai media komunikasinya, terpaan informasi akan lebih sampai pada masyrakat. Melihat jumlah penonton kasus begal di facebook Koran Warta bromo yang begitu besar.

\section{KESIMPULAN}

1. Dalam menjalankan komunikasi organisasi Polres Pasuruan menjadi monitor media online, humas polres pasuruan tidak memberi nasihat kepada manajemen polres. Hanya sebagai pemberi informasi, isu dan opini publik yang di bicarakan masyarakat.

2. Komunikasi organisasi humas dalam membangun opini positif tidak seutuhnya dilakukan, karna humas polres hanya mengandalkan kegiatan tim saber begal dan Satreskrim polres untuk memecahkan masalah yang banyak di bicarakan masyarakat di media online. humas lebih mengarah mengimbangi dengan informasi isu "city of begal" dari pada membangun opini positif kepada masyarakat.

3. Membangun komunikasi (Build communication) peran ini di jalankan oleh hubungan masyarakat polres pasuruan ketika ada masyarakat bertanya melalui media online, sosial media dan call center pengaduan Begal saja, akan tetapi untuk memfasilitasi komunikasi pengaduan masalah kejahatan dan pencurian (Begal) ke polres pasuruan tidak di lakukan oleh humas nya. Tidak ada fasilitator pengaduan di markas polres pasuruan, masyarakat mengadunya langsung ke Kapolres dengan cara di menunggu ketika selasai sholat jum'at.

4. Salah satu komunikasi organisasi yang di jalankan oleh humas adalah komunikator komunikasi, humas polres berperan menyediakan layanan komunikasi dan informasi untuk memberikan dan menyebarluaskan keberhasilan kinerja polres pasuruan dalam menangani opini masyarakat yang negatif di media online.

5. PR Polres tidak memaksimalkan media online dalam membangun opini positif kepada masyarakat, humas lebih memanfaatkan dua media Instagram dan website yang di anggap popular di masyarakat.

6. Humas polres pasuruan memberikan informasi kepada masyarakat bukan untuk membangun opini positif, akan tetapi hanya menginformasikan kinerja tim saber begal.

\section{REFERENSI}

Cutlip, Center dan Broom, 2011. Effective Public Relations. Jakarta : Prenada Media Group.

Deddy Mulyana, 2004. Metodologi Penelitian Kualitatif: Paradigma Ilmu Komunikasi Ilmu Sosial Lainnya. Bandung: Remaja Rosdakarya.

Face dan Faulus.2015. Komunikasi Organisasi : Startegi Meningkatkan Kinerja

Perusahaan. Bandung : PT. Remaja Rosdakarya

Kriyantono, Rachmat, 2008. Teknik Praktis Riset Komunikasi, Kencana Prenada Media Group, Jakarta. 
Kodir, Abdul and Susilo, Daniel. 2015. CSR dan PR: Sinergitas, Kritik, dan Diskursus Budaya Komunikasi Tanggung Jawab Perusahaan. Surabaya: CV. M- Brothers Indonesia.

Meleong, Lexy J. 2001 . Metedologi penelitian kualitatif. Bandung. PT. Remaja Rosdakarya.

Soemirat \& Ardianto. 2010. Dasar-Dasar Public Relation, PT. Remaja Rosdakarya. Bandung

Sugiyono. 2013. Metode Penelitian Kuantitatif, Kualitatif dan R\&D. Bandung : Alfabeta 